\title{
Posset, Franz.
}

Unser Martin: Martin Luther aus der Sicht katholischer Sympathisanten. Reformationsgeschichtliche Studien und Texte 161. Münster: Aschendorff Verlag, 2015. Pp. $177+11$ b/w ill. ISBN 978-3-402-10526-9 (hardcover) €32.

Franz Posset has produced an invaluable work introducing readers to Catholic sympathizers of Luther's thought. Readers are familiarized with four humanists and churchmen from Augsburg and environs who applauded the work of Luther while remaining faithful to Rome: Bernhard Adelmann, Caspar Amman, Vitus Bild, and Kaspar Haslach.

We are first introduced to Bernhard Adelmann (1457-1523), the Augsburg cathedral canon who agreed wholeheartedly with Luther's critique of usury. A distaste for Eck was a significant point of commonality between Luther and Adelmann, even while Adelmann did not concur with Eck's depiction of him as a Lutheran. Adelmann's interest in Luther's thought was an instance of his broader curiosity, which was itself a reflection of the humanistic studies that shaped him. Moreover, unlike Luther, he found that this curiosity need not preclude fidelity to Rome even while he continued to read Luther's evolving work up to the time of his death, some twenty-three years before Luther's.

Posset next explores the work of Caspar Amman (1450-1524) an Augustinian from the Lauingen monastery, who was second only to Reuchlin in fame as a Hebraist of that time. Amman shared Luther's interest in translating the biblical text into German, focusing specifically on the Psalter in advance of Luther's own efforts. Posset provides extensive examples of Amman's translations in parallel with Luther's treatments of the Masoretic text. Amman is clearly identified as a "monastic and biblical humanist" (69) who was an avid reader of Luther, coveting any and every opportunity to add Luther's texts to his library. Although Amman spoke glowingly of Luther-even calling him "our apostle" (unseres Apostels) - it was unlikely that they met, and his disagreement with Luther on how to understand Matthew 16:18 gestures to broader differences that might have contributed to Luther's lack of interest in sustained communication with "these Swabians" (diesem Schwaben) (160). Yet the fact that Amman spent six months in jail for protesting the ban against Luther speaks to his deep appreciation of the reformer's theology.

We next meet Vitus Bild (1481-1529), a Benedictine and monastic humanist from Augsburg. Bild had extensive interaction with Amman; he 
saw Luther as a theologian who showed him the way of "evangelical truth" (160), and described Luther as the "Saviour of Germany" (123). He was an avid collector of Luther's pamphlets and lamented his failed opportunity to meet Luther during the latter's meeting with Cardinal Cajetan in 1518. He also realized the danger of identifying too closely with Luther, and so spoke of him in correspondence using " $\mathrm{M}$ " as a cypher for "our Luther" (117). Bild's interest cooled with further developments in the Reformation; still, Luther remained dear to him, even though by 1525 Reformation publications no longer made their way to his library, where the famous 1520 documents by Luther are conspicuously absent. He died a Benedictine monk in whose heart the Gospel as proclaimed by Luther was "solidly rooted" (134).

The final theologian discussed is Kaspar Haslach (died ca. 1540/41), a preacher in Dillingen. Haslach first studied at Wittenberg where he would have been exposed to well-known humanists in the (at that time) two-yearold university, achieving his baccalaureate in 1505 (predating Luther's years there). Haslach considered Luther an "apostolic man" (apostolischer Mann; 140). He shared Luther's general distaste for Aristotle and Luther's suspicion of the capacity of the will to fulfill God's commandments freely, affirming instead the Lutheran approach to justification. Haslach spoke against the sale of indulgences and so faced scrutiny. Nevertheless, he was unscathed by formal examinations and identified himself with Rome rather than Wittenberg.

Two intriguing questions emerge for this reviewer: why did Luther spurn these sympathizers, and why did they remain resolutely Catholic in their identity? As we look to his conclusion, Posset makes the case that his study has advanced the importance of recognizing the humanist roots of Luther's position. Varying approaches to humanism may, indeed, give some insight into understanding Luther's rather curious lack of interest in these Bavarian theologians. Perhaps one might venture that while these four sought to reconcile humanism with the Church of Rome, Luther engaged humanism in an ad hoc fashion in the service of reforming the Church. Posset's intent to direct the reader to humanism as a shared root for the four thinkers is helpful, yet it is important to understand that Luther's engagement of humanism might be better described as a tool strategically used rather than as a source. These different approaches to humanism may, in part, also answer the question regarding the fidelity of these four to Rome. Humanism emerged within the pluralism of the late medieval church, and readers are given the sense that this 
pluralism offered the freedom to engage with Luther as humanists-without the need to become Lutherans. Posset helpfully draws our attention to our need to rescind from seeing sharp denominational or confessional dividing lines in the ecclesial environment of the time.

This study does much to identify the complexity and so to erase simplistic caricatures of Lutherans and Catholics of that time. Readers are reminded that theologians and preachers of many stripes sought clarity on the identity of the gospel in this era; that the exploration of Sola Scriptura was not unique to evangelicals; that reformation was a project of great interest from the fourteenth century on; and that Luther cannot be understood apart from the late medieval Catholic context. Many of these themes are well rehearsed, but worthy of recollection as Posset draws us into the proper topic of his study: four figures who instantiate a sympathetic and engaged reading of Luther, identified in the four chapters of the work as "our Martin," "our Apostle," "the Saviour of Germany," and "the most sincere Herald of evangelical truth." Readers will also enjoy the many illustrations, wood-cuts, etc. which add to this most worthy effort to provide a fuller picture of this exciting era in the life of the Church and western culture.

ALLEN JORGENSON

Waterloo Lutheran Seminary, Wilfrid Laurier University

\section{Reeves, Eileen.}

Evening News: Optics, Astronomy, and Journalism in Early Modern Europe. Philadelphia: University of Pennsylvania Press, 2014. Pp. 308. ISBN 978-08122-4574-5 (hardcover) US\$69.95.

This book examines the acquisition and consumption of knowledge in early modern Europe, focusing on the transmission of information connected to the fields of journalism, optics, and astronomy. Pointing to the shared language, materials, transference, and function of these three fields, Evening News investigates the cultural anxiety surrounding access to and mediation of sociopolitically and religiously charged news during the Thirty Years' War and the shift into the Copernican world system. Reeves draws on a variety of media sources from different regions in early modern Europe to demonstrate the 